\title{
INDUKSI BIOTEKNOLOGI REPRODUKSI PADA TERNAK KAMBING DI MANADO
}

\author{
Debby Jacqualine Jochebed Rayer ${ }^{1}$, Miryam Pingkan Lonto ${ }^{2}$, \& \\ Revolson Alexius Mege ${ }^{1}$ \\ ${ }^{1}$ Jurusan Biologi, Fakultas Matematika dan Ilmu Pengetahuan Alam, \\ ${ }^{2}$ Jurusan Akuntansi, Fakultas Ekonomi \\ Universitas Negeri Manado \\ ramege@unima.ac.id
}

\begin{abstract}
Abstrak
Bagi masyarakat di wilayah Mapanget, masih menempatkan kambing sebagai salah satu komoditas peternakan andalan dan menjadi bagian yang tidak terpisahkan dalam kehidupan masyarakat karena di samping memiliki nilai strategis dalam perekonomian dan kebutuhan konsumsi protein hewani, juga memiliki nilai adat-istiadat serta tatanan sosial budaya yang hidup di masyarakat. Namun populasi dan produksi ternak kambing terus mengalami penurunan akibat menurunnya daya produksi dan reproduksi ternak kambing milik warga sebagai konsekwensi pemeliharaan lepas bebas sehingga menyebabkan terjadinya perkawinan yang tidak terkontrol atau Imbreeding pada gilirannya terjadi degeneratif mutu genetik. Solusi untuk menyelesaikan permasalahan utama yang telah disepakati bersama dan diterapkan di kelompok mitra adalah dengan melakukan pendekatan pembelajaran orang dewasa (Adragogic Approach) dan pendekatan budaya dan etika (Etics and Aproach) yang dikombinasi dengan aplikasi ilmu pengetahuan dan teknologi usaha ternak kambing. Untuk mengatasi masalah reproduksi maka peternak dibimbing dalam memperbaiki reproduksi kambing melalui aplikasi atau induksi teknologi dengan memanfaatkan PMSG sebagai agen superovulasi. Masyarakat juga dibimbing dalam usaha budidaya kambing dengan reproduksi silang kontrol dalam kandang semi rens. Hasil yang dicapai yaitu telah terlaksana dan terfasilitasi kegiatan deseminasi ilmu pengetahuan dan teknologi serta keterampilan pemeliharaan kambing serta program aksi induksi bioteknologi reproduksi dengan memanfaatkan PMSG sebagai agen superovulasi terhadap induk kambing.
\end{abstract}

Kata Kunci: Produksi dan reproduksi ternak kambing, PMSG.

\section{PENDAHULUAN}

\section{Analisis Situasi}

Kecamatan Mapanget merupakan salah satu wilayah yang memiliki keunikan tersendiri yaitu di samping sebagai satu-satunya wilayah pinggiran di kota Manado yang sebagian besar atau mencapai 78 persen penduduknya berprofesi sebagai petani/peternak tradisional dan beragam profesi ganda lainnya, serta merupakan salah satu wilayah sebagai pemasok kebutuhan pangan (nabati dan hewan) bagi pasar di Kota
Manado. Sewajarnya wilayah Mapanget didalamnya desa Buha sebagai pemasok kebutuhan pangan (jagung, umbi-umbian dan sayuran) karena juga merupakan salah satu wilayah paling luas yaitu mencapai $10.29 \mathrm{~km}^{2}$ atau 15.68 persen dari luas wilayah Manado yang mencapai $157.25 \mathrm{~km}^{2}$ dan sebagian besar yaitu mencapai $7.47 \mathrm{~km}^{2}$ berupa lahan untuk pertanian tanaman perkebunan terutama tanaman kelapa dimana gawangannya dijadikan sebagai lahan penggembalaan ternak sapi dan 
kambing secara lepas bebas maupun untuk tanaman pangan. Keunikan lain juga dari Kecamatan Mapanget adalah merupakan salah satu wilayah dengan penduknya berasal dari berbagai suku di samping yang berasal dari 15 daerah di Sulawesi Utara, juga yang berasal dari beberapa daerah di Indonesia seperti dari Gorontalo, Sulawesi Selatan, Sulawesi Tengah, Jawa dan beberapa daerah lainnya tujuan utama untuk berwiraswasta di kota Manado.
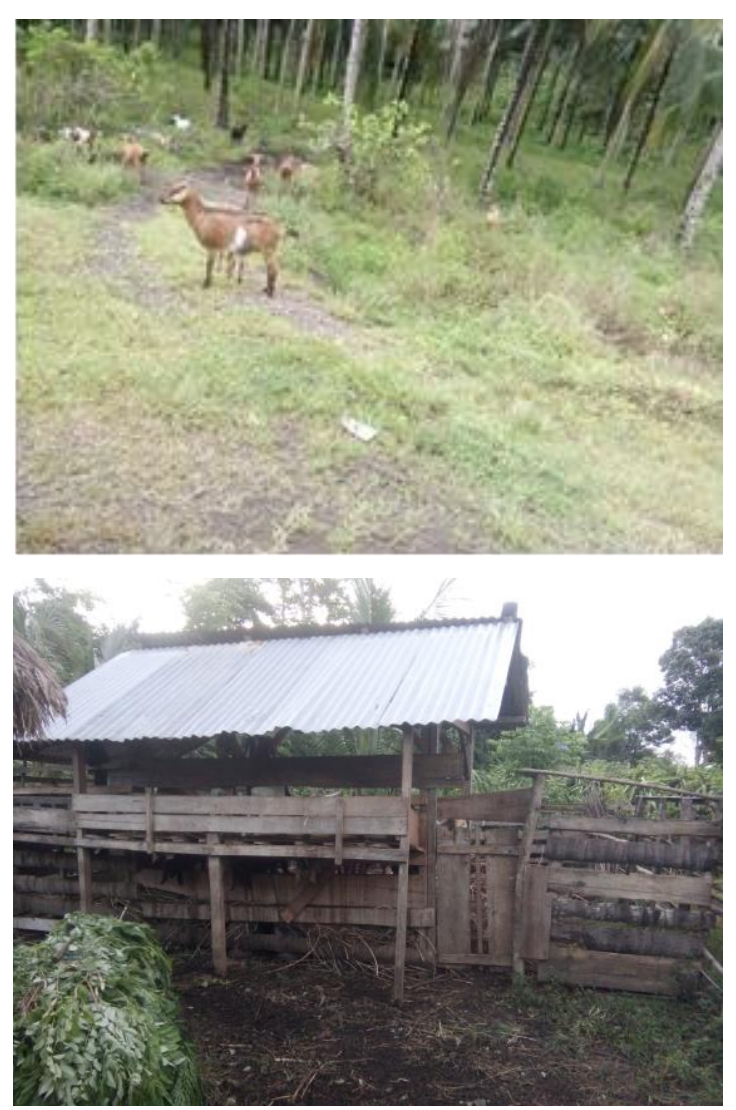

Gambar 1. Gambaran kondisi usaha ternak mitra.

Tidak diperoleh informasi yang jelas, tapi yang pasti bahwa dalam perjalanan waktu sebagian warga pendatang tersebut yang dimotori para ulama, melihat ada potensi dan peluang usaha lain selain berusaha tani dan berdagang yaitu memelihara ternak antara lain ternak sapi dan kambing. Hal ini sangat dimungkinkan karena selain tersedia lahan yang luas di bawah gawangan kelapa, juga ada pengalaman serta peluang pasar untuk usaha-usaha tersebut terutama memelihara ternak kambing. Sebagaimana diketahui bahwa kambing tidak saja dikenal dengan ternak multi produk karena menghasilkan daging, susu (tipe perah), juga bulu/kulit, kotoran untuk pupuk organik dan manfaat lainnya (Anonimus, 2011; Rasmati, 2013). Oleh karena itu walaupun proses reproduksinya lambat, tetapi ternak kambing banyak digemari dan dipelihara oleh masyarakat petani (Murdjito dkk., 2011).

Potensi pengembangan ternak kambing sangat terbuka luas dari segi pemenuhan konsumsi maupun peluang pasar. Data Dinas Agribisnis Kota Manado menunjukkan bahwa dari tahun ke tahun terus terjadi kenaikan kebutuhan daging kambing. Hal ini terlihat dari tahun 2010 terjadi peningkatan kebutuhan konsumsi atau jumlah kambing yang dipotong yaitu sebanyak 1070 ekor, naik menjadi 1471 ekor pada tahun 2015. Diperkirakan kebutuhan kambing untuk kota Manado terus mengalami peningkatan. Berdasarkan analisis potensi kebutuhan ternak, akan terjadi peningkatan jumlah kambing untuk kota Manado melebihi kebutuhan tahun 2015. Hal ini memberi gambaran bahwa peluang untuk usaha ternak kambing bagi 
kedua Mitra sangat terbuka luas dan menjanjikan apabila usaha tersebut dilaksanakan secara intensif dan secara terintegrasi dari kedua Mitra PKM.

\section{Permasalahan Mitra}

Bertolak dari analisis situasi dan rangkaian permasalahan tersebut di atas maka telah disepakati bersama dengan kedua mitra beberapa permasalahan utama yang akan diselesaikamn secara bersama yaitu:

1. Rendahnya pengetahuan dan keterampilan mitra dalam berusaha ternak kambing, terlebih dalam upaya memperbaiki dan mempertahankan mutu genetik kambing lokal;

2. Pemeliharaan ternak yang lepas bebas telah berakibat terjadi perkawinan yang tidak terkontrol atau Imbreeding yang pada gilirannya terjadi penurunan mutu genetik kambing kacang unggul, sehingga selain menurunkan kemampuan induk untuk menghasilkan bobot dan jumlah anak yang optimal dalam satu siklus reproduksi, juga tidak jarang dihasilkan anakan yang kerdil. Bahkan banyak mengalami gagal bunting dan bahkan gagal birahi, dimana betina yang sudah umur kawin tapi tidak nampak gejala birahi; dan

3. Belum ada upaya penanganan kotoran ternak oleh mitra di samping berdampak pada kesehatan lingkungan kandang, juga telah menjadi sumber penyebaran bibit penyakit, pada satu sisi terdapat potensi kotoran yang sangat besar untuk diolah atau difermentasi menjadi pupuk cair dan pupuk organik padat yang memberikan nilai tambah secara ekonomi dan dapat membantu ketersediaan pupuk untuk tanaman pangan dan hijauan ternak.

\section{Solusi Permasalahan}

Solusi terhadap permasalahan mitra yang dapat dilakukan adalah sebagai berikut:

1. Melaksanakan deseminasi teknologi dalam upaya meningkatkan pengetahuan dan keterampilan berusaha ternak kambing; dan

2. Dalam rangka pemulihan mutu genetik kambing lokal (kambing kacang) untuk meningkatkan kemampuan induk menghasilkan bobot dan jumlah anak yang optimal dalam setiap siklus reproduksi maka beberapa langkah solusi yang harus dilakukan adalah:

a. Program aksi introduksi dan seleksi bibit dan induk serta pejantan unggul;

b. Program aksi induksi bioteknologi reproduksi dengan memanfaatkan PMSG sebagai agen superovulasi terhadap induk kambing milik mitra.

\section{METODE PELAKSANAAN}

\section{Metode dan Pendekatan}

Dalam upaya menyelesaikan permasalahan masyarakat khususnya mitra peter- 
nak kambing maka sangat diperlukan kombinasi metode "Transformasi Ilmu Pengetahuan dan Teknologi" berbasis Masalah dengan pendekatan Andragogik dan Pendekatan Budaya dan Etika, sehingga masyarakat dapat terbebas dari kungkungan permasalahan yang selama ini dihadapi oleh Mitra dan bermuara pada pemberdayaan masyarakat. Pendekatan-pendekatan yang akan dilakukan dalam upaya melengkapi pelaksanan metode kegiatan tersebut adalah sebagai berikut:

1. Pendekatan Andragogik merupakan suatu pendekatan yang digunakan untuk transformasi pengetahuan dan teknologi serta keterampilan secara informal kepada suatu komunitas atau anggota masyarakat dewasa dari segi usia dengan teknik pembelajaran spesifik. Spesifikasi pembelajaran yang lazim digunakan pada pembelajaran orang dewasa antara lain ketika transformasi ilmu pengetahuan dan teknologi serta keterampilan di samping dilakukan dengan cara pendampingan secara berkelompok, juga dilakukan secara individu. Hal ini mendorong kelompok sasaran mengambil tanggung jawab yang luas termasuk mengambil keputusan keikutsertaanya dalam kegiatan ini. Selanjutnya teknik pembelajaran yang akan digunakan merupakan kombinasi dari penggunaan buku yang berkaitan dengan usaha tani dan ternak, tutorial, diskusi dan kerja kelompok, curah pendapat (brainstorming) serta pemberdayaan masyarakat; dan

2. Pendekatan etika dan budaya intinya adalah setiap individu manusia apapun kedudukannya dalam strata sosial pada hakekatnya membutuhkan pengakuan, penghormatan dan penghargaan dalam hidupnya. Pendekatan budaya sangat diperlukan mengingat masyarakat desa Buha walapun terdiri dari beragam, suku, namun memiliki nilai historis yang unik, sehingga sangat menjunjung nilai budaya dan etika. Oleh karena itu tim pelaksana harus memahami benar karakter dan etika sosial masyarakat setempat.

\section{Pelaksanaan Kegiatan Induksi Bioteknologi Reproduksi}

Untuk menjawab permasalahan penurunan produktivitas induk maka sangat penting mitra memahami aspek reproduksi. Salah satu langkah yang akan dilakukan adalah dengan menginduksi teknologi reproduksi terutama memanfaatkan hormon tertentu seperti penggunaan PMSG pada induk yang potensial untuk mendapatkan bibit unggul hasil induksi hormon reproduksi yang menstimulasi folikel. Mitra juga diberi pemahaman dan dibimbing untuk pengenalan ciri masa birahi/estrus, teknik perkawinan alami atau persilangan terkontrol dalam rangka memulihkan dan mendapatkan kembali keunggulan kempetitif 
atau plasma nutfah kambing lokal. Hal lain yang diperkenalkan kepada mitra adalah teknik membantu persalinan, pemilihan bibit, proses produksi meliputi pemeliharaan anakan, pemeliharaan starter/grower dan finisher serta penanganan pasca panen.

\section{Implementasi Teknologi}

Dalam bagian ini, Mitra dituntun dalam proses aplikasi teknologi reproduksi terutama memiliki keterampilan mulai dari melakukan penyerantakan birahi dengan menggunakan prostaglandin ( $\left.\mathrm{PGF}_{-2 \alpha}\right)$. Dua minggu setelah penyerantakan birahi akan dilakukan penyuntikan ulang penyuntikan PGF${ }_{2 \alpha}$ kedua pada pagi harinya dan pada sore harinya dilakukan penyuntikan PMSG dalam formula PG-600. Setelah perlakuan hormon PMSG dalam formulasi PG-600, mitra dituntun untuk memahami dan memiliki pengetahuan mengenal ciri-ciri masa birahi atau estrus pada kambing, bahkan menuntun kambing melakukan perkawinan alami (silang terkontrol), membantu persalinan kambing, dan merawat anakan, melakukan seleksi calon bibit dan aktivitas lain yang berkaitan dengan masalah reproduksi. Untuk menunjang pelaksanaan kegiatan ini terutama memperbaiki mutu genetik kambing lokal maka akan dilakukan pemilihan dan diintroduksi juga induk unggul.

\section{HASIL DAN PEMBAHASAN}

Suatu kegiatan penerapan IPTEKS sebagai upaya meningkatkan pendapatan ekono- mi masyarakat miskin di daerah perbatasan melalui penerapan teknologi superovulasi pada ternak kambing telah dilaksanakan. Kegiatan ini dirasakan sangat bermakna dan dipandang sebagai salah satu upaya nyata dan bergayut untuk merealisasikan pemecahan permasalahan di atas.

Sebagaimana diuraikan dalam metode kerja, bahwa sebelum implementasi teknologi dilakukan evaluasi awal untuk mengetahui potensi dasar atau tingkat penguasaan pengetahuan dan keterampilan tentang usaha ternak kambing khususnya berkaitan dengan perbaikan reproduksi yang menggunakan berbagai teknologi reproduksi antara lain dengan menggunakan superovulasi. Berdasarkan hasil evaluasi melalui wawancara menunjukkan bahwa hampir sebagian besar atau mencapai 95 persen masyarakat telah mengenal system reproduksi atau perkawinan pada kambing, tetapi juga sebesar 95 persen masyarakat peternak belum mengenal berbagai teknologi reproduksi pada kambing seperti superovulasi dan tekologi lainnya. Hasil evaluasi juga menunjukkan bahwa sebagian besar peternak belum pernah mempraktekkan atau melakukan intervensi proses reproduksi pada kambing secara sederhana seperti dimulai dari pemilihat bibit tepat, pemeliharaan induk dan pejantan unggul sampai pada usaha perkawinan dengan silang control Sehingga praktis seluruh kegiatan usaha pemeliharaan ternak yang dijalankan oleh masyarakat masih bersifat tradisional. 
Sebagai tindak lanjut dari hasil evaluasi tersebut terutama dalam menjawab tujuan kegiatan penerapan IPTEKS ini dengan beberapa indikator output maupun outcame maka telah diambil langkah konkrit untuk realisasi program pemberdayaan masyarakat peternak ini. Upaya yang dilakukan adalah memfasilitasi upaya peningkatan pengetahuan dan keterampilan melalui kegiatan deseminasi atau penyuluhan kepada masyarakat tentang reproduksi ternak kambing antara lain memberikan pengetahuan tentang teknologi superovulasi bagi peternak.
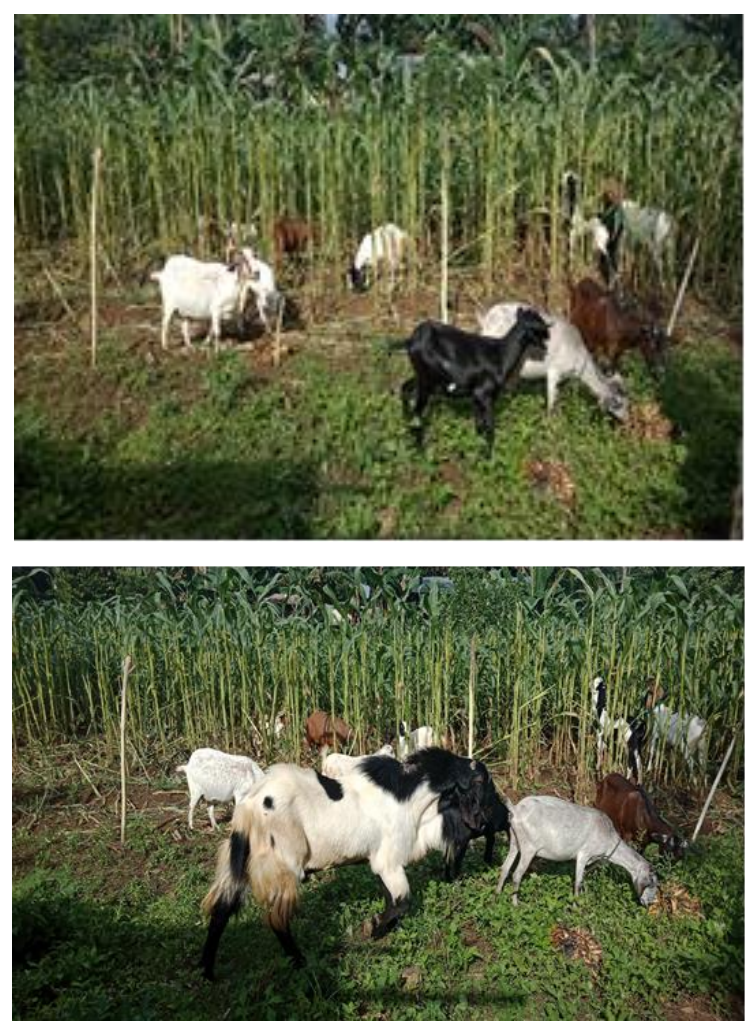

Gambar 2. Potensi imbreeding dengan mudah terjadi ketika kambing dilepas bebas.

Kegiatan lain yang dilakukan adalah memberikan pengetahuan dan keterampilan melakukan atau mempraktekkan proses superovulasi pada kambing milik mitra. Di samping itu juga dalam kegiatan ini masyarakat diberikan pengetahuan tentang pemeliharaan ternak mulai dari pemilihan bibit yang baik, pemeliharaan induk dan pejantan, pembuatan kandang dan manajemen pakan serta kesehatan bagi ternak.
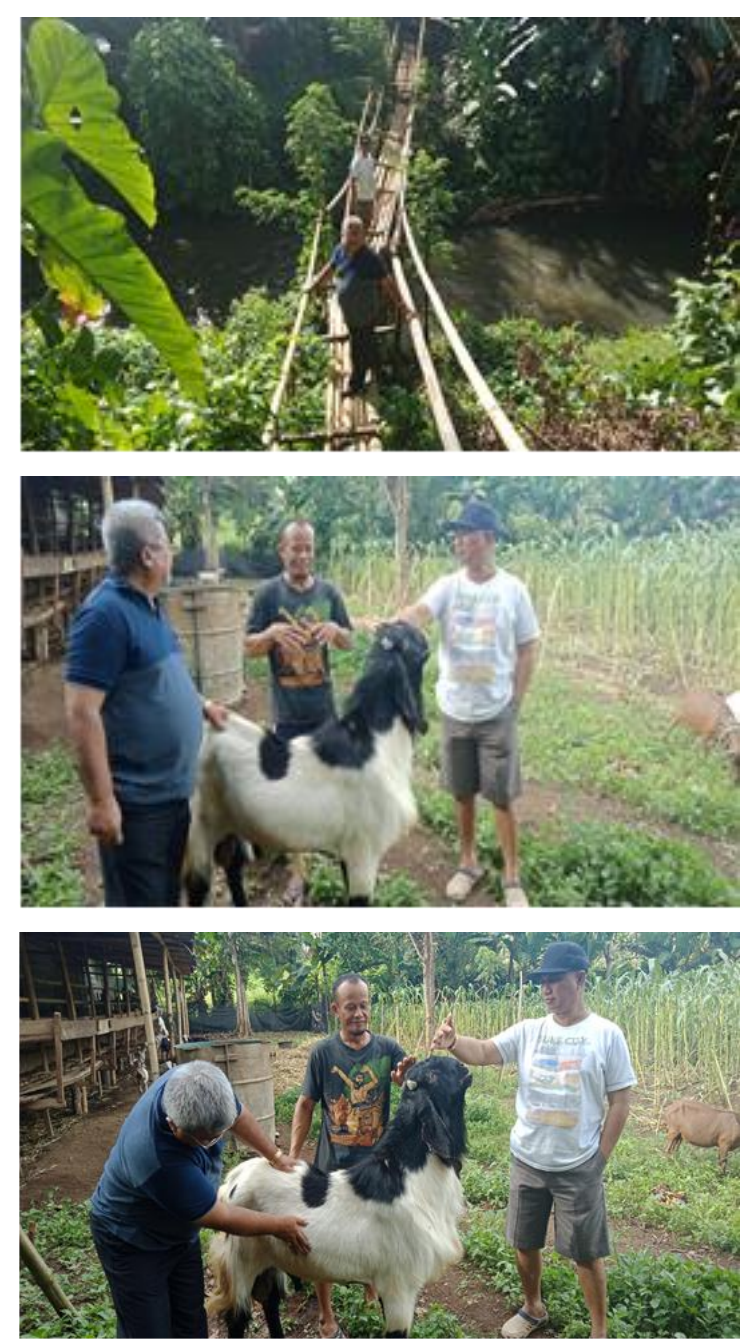

Gambar 3. Rangkaian kegiatan observasi kondisi induk dan penyerahan pejantan unggul dalam rangka perbaikan mutu genetik kambing milik mitra.

Berdasarkan hasil evaluasi akhir program menunjukkan bahwa hampir sebagian besar atau mencapai 90 persen mitra dan 
masyarakat di samping telah mengenal proses perkawinan atau reproduksi pada kambing tetapi juga sebagian besar atau 95 persen masyarakat peternak telah mengenal berbagai teknologi reproduksi pada kambing seperti superovulasi dan tekologi lainnya. Hasil evaluasi akhir program juga menunjukkan bahwa sebagian besar peternak yaitu mencapai 90 persen telah memiliki pengetahuan dan keterampilan dan mampu mempraktekkan atau melakukan intervensi proses reproduksi pada kambing secara sederhana seperti dimulai dari pemilihan bibit tepat, pemeliharaan induk dan pejantan unggul sampai pada usaha perkawinan dengan silang kontrol. Pemecahan masalah mitra telah tercapai dengan terlaksananya dan terfasilitasi upaya peningkatan pengetahuan dan keterampilan tentang teknologi superovulasi bagi mitra kegiatan. Juga kegiatan ini mencapai sasaran atau tercapainya output dengan disuperovulasinya 11 ekor induk kambing milik anggota masyarakat. Output juga terukur dengan penambahan 4 ekor induk baru dan 1 ekor pejantan unggul. Hal ini dilakukan mengingat induk kambing yang tersedia selain sudah lewat umur produksi, juga telah mengalami imbreeding.

\section{KESIMPULAN DAN SARAN}

\section{Kesimpulan}

Berdasarkan hasil kegiatan Program Kemitraan Masyarakat di Buha Manado telah terlaksana dengan baik dengan hasil:
1. Telah terlaksana dan terfasilitasi kegiatan deseminasi ilmu pengetahuan dan teknologi serta keterampilan pemeliharaan kambing; dan

2. Telah terfasilitasi deseminasi teknologi dan program aksi seleksi bibit dan induksi bioteknologi reproduksi dengan memanfaatkan PMSG sebagai agen superovulasi terhadap induk kambing.

\section{Saran}

Agar program pemberdayaan masyarakat melalui kegiatan PKM dapat berjalan secara berkesinambungan maka diperlukan upaya serius dari berbagai pihak dalam menunjang dan melakukan pendampingan dalam upaya membantu masyarakat peternak dalam mengembangkan usaha ternak sebagai bagian dari upaya membantu program pemerintah untuk penyediaan pangan hewani.

\section{KEPUSTAKAAN}

Adriani, Sutama IK, Sudono A, Sutardi, Manalu,W. 2004. Pengaruh superovulasi sebelum perkawinan dan suplementasi seng terhadap produksi susu kambing peranakan etawah. Animal Production 6:86-94.

Anonimus. 2011. Kambing Peranakan Etawa Sumberdaya Ternak Penuh Berkah. Badan Litbang Pertanian. Edisi 19 (3427) Tahun X: 5-13. http://www.litbang.pertanian.go.id. [2 April 2015].

Manalu W, Sumaryadi MY, Sudjatmogo, Satyaningtijas AS. 2000a. Effect of superovulation prior to mating on milk 
production performance during lactation in ewes. J. Dairy Sci. 83:477-483.

Manalu W, Sumaryadi MY, Sudjatmogo, Satyaningtijas AS. 2000b. The effects of superovulation of Javanese thin-tail ewes prior to mating on lamb birth weight and preweaning growth. Asian-Aus. J. Anim. Sci. 13::292-299.

Mege, R. A., W. Manalu, N. Kusumorini dan S. H. Nasution. 2006. Pengaruh Superovulasi terhadap Produksi Anak Babi, Anim. Production. 8 (1) : 8 - 15.

Mege, R. A., S. H. Nasution, N. Kusumorini dan W. Manalu. 2007. Pertumbuhan dan Perkembangan Uterus dan Plasenta Babi dengan Superovulasi. HAYATI Jurnal of Bioscience. 14 (1) : 1 - 6.

Mege, R. A., Saerang, J. L. P., Manopo, J. H. And A. A. Maramis. 2015. Community Empowerment trough facilitation of crop corn farming in Bulude Village Talaud Islands, North Sulawesi. Proceedings of International Conference on Mathematics, Natural Sciences, and Its
Education, FMIPA Universitas Negeri Manado.

Mege, R. A., Saerang, J. L. P., Manopo, J. H. And A. A. Maramis. 2016. Fasilitasi Peternakan Babi Berbasis Sumberdaya Lokal bagi Masyarakat Desa Bulude Kabupaten Kepulauan Talaud. Seminar Nasional Hasil Penelitian dan Pengabdian kepada Masyarakat 29-30 Agustus 2016. "Inovasi IPTEKS Perguruan Tinggi untuk Meningkatkan Keejahteraan Masyarakat. Hal. 577 - 585.

Murdjito, G., I G.S. Budisatria, Panjono, N. Ngadiyono, dan E Baliarti. 2011. Kinerja Kambing Bligon yang Dipelihara Peternak di Desa Giri Sekar, Panggung, Gunung Kidul. Buletin Peternakan, 35 (2): 86-95.

Rasminati, N. 2013. Grade Kambing Peranakan Ettawa pada Kondisi Wilayah yang Berbeda. Sains Peternakan Vol. 11 (1) : 43-48 